Padjadjaran Nursing Journal (Jurnal Keperawatan Padjadjaran)

ISSN 2338-5324 (print)

ISSN 2442-7276 (online)

Online di http://jkp.fkep.unpad.ac.id

DOI : $10.24198 / \mathrm{jkp}$

\title{
Relationship between Age, Gender, and Peer Group with Reproductive Healthy Behavior of Teen
}

\author{
Tetti Solehati ${ }^{1}$, Agus Rahmat ${ }^{2}$, Cecep Eli Kosasih ${ }^{3}$, Nur Oktavia Hidayati ${ }^{4}$ \\ ${ }^{1,3,4}$ Faculty of Nursing Universitas Padjadjaran, ${ }^{2}$ Faculty of Communication Universitas Padjadjaran \\ Email:tsh_tetti@yahoo.com
}

Submitted: 28-12-2018 Accepted: 27-7-2018 Published: 11-8-2018

\begin{abstract}
Adolescent reproductive health (KRR) in Indonesia is still poor. The KRR known as Triad KRR consisted of sexuality, HIV / AIDS, and drugs become a national problem. Teenagers were more comfortable talking about their KRR with their friends than their parents or teachers. The purpose of this research was to know the relation of age, gender, and peer group with behavior of adolescent reproductive health. The research method was cross sectional study design. Data were analyzed using descriptive statistic, Chi-square and binary logistic. Research conducted in 2017 in junior and high school district Bandung. The population of this study was all students of SMP and SMA amounted to 12,000. The samples amounted 668 students. The results of the research showed that there was a significant relationship between gender with behavior $(p=0,006)$, there was a significant relationship between age and behavior $(\mathrm{p}=0,031)$, and there was a significant relationship between peer group and behavior $(\mathrm{p}=0,042)$. Multivariate analysis found that age had opportunity 0,527 times, peer group had opportunity 0,211 times, and gender 2,208 times on the behavior support of Triad KRR. The results concluded that KRR behavior is influenced by age, sex, and peer group. Based on the results of the study suggested for the provision of education using a method that involves peer group by considering the age and gender in improving knowledge, adequate and sustainable behavior especially about adolescent reproductive health.
\end{abstract}

Keywords: Age. behavior, gender, peer group. 
Tetti Solehati: Relationship between Age, Gender, and Peer Group with Reproductive Healthy

\section{Introduction}

Bandung regency is one part of metropolitan development area in Indonesia, has very high Population Growth Rate (LPP) reaching $2.56 \%$ per year mostly caused by migration to this region to look for work (Bandung Regency Government, 2013). This condition causes the vulnerability to behave freely in his teenage lifestyle. In the study of Suryoputro et al. (2006) mentioned that Indonesian adolescents were currently experiencing rapid social change from traditional society to modern society due to urbanization and industrialization, changing their norms, values, and lifestyles due to rapid urbanization and industrialization. This has resulted in increased vulnerability of children and adolescents to various diseases and threats, especially those related to adolescent reproductive health, such as drug use, free sex where both deviant behaviors cause adolescents at high risk of contracting HIVAIDS.

Reproductive health is very important because it is closely related to the quality of human life in the future which is very decisive for the future of human life. According to BKKBN (2006), reproductive health is a condition free from unwanted pregnancies, unsafe abortion, sexually transmitted diseases (STDs), HIV/AIDS, and free from all forms of sexual harassment and violence. Teens reproductive health is a healthy condition concerning the reproductive system (functions, components and processes) that teens possess both physically, mentally, and socially. Adolescent behavior that supports reproductive health is expected to be able to maintain reproductive health so as to enter the period of family life with healthy reproduction. Unfortunately there are still many problems of reproductive health in adolescents today.

Adolescent problems occur, because teenagers were not prepared for the knowledge they need to have about aspects relating to the transition from childhood to adulthood (Azza, 2016). Inadequate knowledge and misinformation on adolescent reproductive health may affect risky behavior in adolescents known as the three primary threats to adolescent reproductive health or the Triad of Reproductive Health (TRIAD KRR), including sexuality (sexual violence, unmarried pregnancy, early marriage, free sex), HIV/AIDS, and drugs (BKKBN, 2006). This is supported by the Lestary and Sugiharti (2011) studies that knowledge is one of the factors related to risk behavior in adolescents in Indonesia.

Unhealthy sexual behavior among unmarried adolescents tends to increase. Some research results shown that adolescents aged 15-24 years have had pre-marital sexual intercourse $1 \%$ in women and $6 \%$ in men, dating experience in Indonesia tends to be more daring and open like holding hands (men 69\% and women 68.3\%, kissing (male $41.2 \%$ and female $29.3 \%$, fingering (male $26.5 \%$ and female 9.1\%) (SKRRI, 2007) Research conducted by various institutions in Indonesia found that $5-10 \%$ of women and $18-38 \%$ of men aged $16-24$ years had premarital sexual intercourse with partners of their age (Hatmadji 1993; Ford, 1997). The issue of reproductive health in adolescents is the desire to know the problem in connection with reproduction, especially sexual problems and NAFZA even wanted to try it.

Another problem that threatens teens is drug abuse. Based on data from the National Narcotics Agency in 2008, shown the number of drug users until the year 2008 was 115,404 , of which 51,986 of them were aged 16-24 years, among them was adolescent school students amounted to 5.484.Kasus drug in Bandung regency in 2010 recorded 63 cases with number of suspects 91 people (www. bandungkab.go.id).

HIV/AIDS is also a prominent issue in adolescents. The number of new AIDS cases in the period of January-September 2011 was 1805. Cumulative AIDS cases up to June 2011 amounted to 26,483 cases, 45.9\% (Kemenkes RI, 2012). The data is an iceberg phenomenon (only those reported only). New AIDS symptoms appear after 3-10 years of infection, so it is likely that most of those affected by AIDS have been infected at a younger age. The number of HIV/AIDS patients in Bandung regency until the end of 2013 was recorded 106 people (www. bandungkab.go.id).

For health and safety, children need to be equipped with knowledge about the dangers 
Tetti Solehati: Relationship between Age, Gender, and Peer Group with Reproductive Healthy

of drugs, so they can live healthy from both physical and mental. Precise preventive measures against drug use are important in informing teenagers, given that Indonesia is now in a "Drug emergency" situation. With the increasing number of troubled adolescents, it will disrupt the achievement of individual adolescent growth and development tasks (physical growth, mental development, emotionally and spiritually and the task of social growth and development (BKKBN, 2012).

According to Interview with Promkes UPTD Puskesmas Dayeuhkolot Regency Bandung obtained that there is no incidence rate data about the disease in KRR adolescent due to the teenagers was keep closed during interview about KRR. The data from teachers at school was found that the UKS program was not working, so that it did not have the human resources responsible for the implementation of the UKS, almost all schools had no school health cadres, no training on school health cadres, BK teacher training on KRR and PIK-R ever done . For regular HIV and drug abuse conducted every 3 months by the police team, while reproductive health education was conducted in December 2016 by a team from Jakarta joint nurses and doctors. According to data from BKKBN Kabupaten Bandung, schools in 31 sub-districts of Bandung Regency have several programs to improve KRR behavior, such as GenRe, BKR, PIK-R. The PIK-R driver in the school is the BK teacher and the counselor is the principal or teacher. Teenage health cadres are voluntary no special responsibility. According to students who attend school in Bandung regency, PIK-R survives 2 years and no one goes on, there has never been any special socialization activities on adolescent reproductive health from schools, UKS has no administrators and programs, UKS is only a place where students are sick only. For the KRR problem in his school there was once 1 person using drugs but had been expelled from school, and there were also 2 female students who were pregnant out of wedlock.

The existence of adolescents is an asset of the nation that should be noticed by the government and society in a system so that they can optimize the task of development in accordance with the stages of his age. Looking at the very large number, then children and adolescents as the next generation of the nation needs to be prepared to be a healthy man physically, mental and spiritual. But in fact, studies shown that adolescents have a very complex problem with the transition period experienced by adolescents. The need for prevention of their KRR problems in the form of educational strengthening. In addition, not only strengthening in the field of education for children and adolescents, but also another important thing is their own support (peer group support), so that among them complement each other, remind and support to improve reproductive health of children and adolescents. According to Green and Kreuter (2005) said that the cause of behavior of one of them was peers. Behavior can also be affected by age and gender. Mahmudah Research (2016) showed that the sexual behavior of high school adolescents in the city of Padang was influenced by sex. Mesra and Fauziah (2015) research on high school adolescents in Tangerang gender related premises sexual behavior. Research Solehati (2017) found that age had a relationship with the behavior of adolescent girls in boarding school in Garut.

In adolescence if it seen from the development of activities, school-aged children are beginning to move away from family groups and focus more on relationships with their wider peers and prioritizing social cooperation (Wong, Hockenberry, Wilson, Winkelstein, \& Schwartz, 2009). Teenagers feel comfortable when discussing or sharing secrets with their peers rather than to parents, they rely on their support and intimacy to their peers. In adolescence, peer group is a very influential factor in adolescent life which provides a sense of belonging and provides opportunities for learning behaviors that they can accept (Wills, 1999; Potter \& Perry, 2005). In a peer group, a person will feel the same good age / needs / goals, a sense of responsibility for the success and failure of his group, interact and provide the spirit and motivation of other peers emotionally, can find himself personally and can develop a sense social in line with the development of his personality. Research Grace (2013) 
Tetti Solehati: Relationship between Age, Gender, and Peer Group with Reproductive Healthy

to junior high school students in Makassar showed that there was a relationship between peer group interactions with behavioral changes. Pramono's research (2011) in high school students in Samarinda showed that peers influence sexual behavior in adolescents. The Tome (2012) study of 6th, 8 th and 10th grade children in Europe showed that peers influence both good behavior and bad behavior.

Peer Group Support is defined as emotional social support, instrumental support, and sharing in any condition to bring about desired social or personal change (Solomon, 2004). Peer Group Support has a function as companionship, positive stimulation, psysical support, ego support, and intimacy / affection (Dariyo, 2004). The more trust and openness with others is one of the characteristics of the Peer Support Group. Another feature is that there is a joint responsibility effort and there is communication that allows to express their needs to each other without threats or coercion, assuming full reciprocity, assuming systemic evolution as opposed to individual recovery of the problem, requiring people to rethink the meaning of salvation (Mead \& MacNeil, 2005). In Peer Group Support, there are 3 supporting aspects: emotional support, instrumental support, and information support (Solomon, 2004). Peer Group Support has proven successful in improving behavior for the better. In his research Zahroh (2015) states that Peer Group Support has a very important role for the development of adolescents both emotionally and socially. Some studies suggest that Peer Group Support has an important effect on adolescent behavior (Tome, 2012; You, 2011; Albert, 2013; Crosnoe, 2008; Tome, 2012). Delisle (2016) in his review literature states that peer facilitators play an important role in determining the success of many support groups. These studies only reveal the influence of peer groups on behavior in general, does not reveal how the influence of peer group on behavior of adolescent reproductive health.

Therefore, based on problems that occur about adolescent reproductive health in Bandung Regency and previous research hence required analysis to reveal relationship of age, gender, peer support group (peer support group) with behavior of KRR.

\section{Method}

In this study, quantitative research design was used with cross sectional design to analyze the peer group relationship with KRR behavior. The study was conducted in Kabupaten Bandung, namely SMP 1 Banjaran, SMP 1 Dayeuhkolot, SMP 1 Cileunyi, SMA Dayeuhkolot, and Cileunyi High School from July to December 2017. This location was selected because based on the study by the teams with local government on behavior less supportive of adolescent reproductive health in the area that causes child and adolescent reproductive health problems is quite high. In addition, the high risk of children and adolescents experiencing reproductive health problems due to the high migration to this region and its status as a development area of Bandung metropolitan. The total population of all junior high school and high school students was 12.000 , with Slovin formula obtained sample of 668 students. Sampling technique with stratified random sampling. This study has obtained research permission from National Unity and Politics Agency 070/1250 / Bakesbangpol, all participants in this study were given informed consent to homeroom teacher and parents before data collection was started and willing to participate in this research. The data collection was done by filling the demographic data instruments of age and sex, as well as questionnaires about the behavior of Triad KRR (sexual, drugs, HIV / AIDS) and peer group using Likert scale. In the process of filling questionnaires assisted by field data collectors a number of 4 people S1 Nursing who have done apersepsi first. Data were analyzed by using descriptive statistical analysis, Chi square, and multiple logistic regression. Descriptive statistical analysis in the form of frequency and percentage was used to see the description of age, gender, behavior, and peer group. Chi square analysis and multiple logistic regression were used to analyze the relationship of age, sex, and peer group to KRR behavior using. 
Tetti Solehati: Relationship between Age, Gender, and Peer Group with Reproductive Healthy

\section{Result}

The results of this study explained the characteristics of respondents, as well as the relationship between age, sex, and peer group. For more details, the data seen in Table 1 and Table 2 below.
From Table 1, it showed that the average age of students was 14.55 years $(\mathrm{SD}=1.68)$. More than half of the women were $57.6 \%$. Almost all of them behaved in support of $92.4 \%$. Almost all students had a strong peer group of $97.5 \%$.

Table 1 Frequency Distribution Characteristics of Age, Gender, Behavior, and Peer Group Students $(\mathrm{n}=668)$

\begin{tabular}{|c|c|c|}
\hline Variable & $\mathrm{f}$ & $\%$ \\
\hline Age (year) & 335 & 50.1 \\
\hline $10-14$ & 333 & 49.9 \\
\hline $15-19$ & & $\mathrm{M} \square \mathrm{SD}=14,55 \square 1,68$ \\
\hline Gender & 385 & 57.6 \\
\hline Female & 283 & 42.4 \\
\hline Male & 51 & 7.6 \\
\hline Behavior & 617 & 92.4 \\
\hline Does not Support & & 97.5 \\
\hline Support & 651 & 2.5 \\
\hline Peer Group & 17 & \\
\hline Strong & & \\
\hline Weak & & \\
\hline
\end{tabular}

Table 2 Relationship of Age, Gender, and Peer Group with KRR Behavior On Students of Year 2017 ( $N=668)$.

\begin{tabular}{|c|c|c|c|c|}
\hline \multirow{2}{*}{ Variable } & \multicolumn{2}{|c|}{ Behavior of Triad KRR } & \multirow{2}{*}{$\square 2$} & $\mathrm{p}$ \\
\cline { 2 - 3 } & Does not support & Support & & \\
\hline Gender* & & & & 0.006 \\
\hline Female & 20 & 365 & 7.672 & \\
\hline Male & 31 & 252 & & 0.031 \\
\hline Age* & & & & \\
\hline $10-14$ & 33 & 302 & 4.680 & \\
\hline $15-19$ & 18 & 315 & & 0.042 \\
\hline Peer Group* & & & & \\
\hline Strong & 47 & 604 & 4.151 & \\
\hline Weak & 4 & 13 & & \\
\hline
\end{tabular}

Table 3 Result Of Logistic Regression Test

\begin{tabular}{|c|c|c|c|c|c|c|c|c|}
\hline \multicolumn{9}{|c|}{} \\
\hline Variabel & B & S.E. & Wald & Df & Sig (p) & Exp (B) & Lower & Upper \\
\hline Age & -.640 & .309 & 4.293 & 1 & .038 & .527 & .288 & .966 \\
\hline $\begin{array}{c}\text { Peer } \\
\text { Group }\end{array}$ & -1.554 & .615 & 6.395 & 1 & .011 & .211 & .063 & .705 \\
\hline Gender & .792 & .302 & 6.887 & 1 & .009 & 2.208 & 1.222 & 3.991 \\
\hline Constant & -1.926 & .765 & 6.333 & 1 & .012 & .146 & & \\
\hline
\end{tabular}


Tetti Solehati: Relationship between Age, Gender, and Peer Group with Reproductive Healthy

Table 2 showed that there was a relation between gender and behavior $(\mathrm{p}=0.006)$, there was correlation between age with behavior $(\mathrm{p}=0.031)$, and relationship between peer group and behavior $(\mathrm{p}=0.042)$.

Based on the above Table, it was found that the age of opportunity 0,527 times to behave in favor of KRR means that the age group of 15-19 year has a bigger chance to support KRR, peer group has 0.211 chance to support KRR means the stronger peer group support KRR, and gender 2.208 times behave supporting KRR means women have a bigger chance to support KRR. The regression equation formed from the logistic regression analysis is: $\operatorname{Ln}$ (behavior) $=-1.926-.640$ age1.926 peer group +1.554 sex + e.

\section{Discussion}

The results showed that the average age of students was 14.55 years $(\mathrm{SD}=1.68)$, more than half of female respondents were 385 (57.6), almost all respondents had a behavior of supporting the KRR of $666(99.7 \%)$ and almost all respondents have a strong peer group of $651(97.5 \%)$.

In the adolescent KRR behavioral variable found that it was in the cathagoric of support. This is possible because there are several factors that influence the behavior of the adolescent, such as the existence of religious activities before the lesson begins, led by the head of the class and their teachers. In addition the teachers are also quite hard in applying the discipline to their students in matters relating to the opposite sex. The existence of rules about what is allowed and something that is prohibited by parents at home and teachers in schools that menyebkan them have attitudes and behaviors such support. The results of Anesia (2013) indicated that parental control has a relationship with premarital sexual behavior. This shows that the parental controls influence the behavior of adolescent KRR. In addition, the possibility of the influence of norms and religion in Bandung regency that prohibits teenagers to get along freely and mengggap sexual is something sacred. According to Anindani (2015), people's lives were full of Eastern life values dominated by religious and cultural teachings that govern one's life, including one's sexual behavior.

Teen age is an age in critical times where the curiosity is very high, but they feel awkward to ask parents and teachers. This is because it is still less open the parents and teachers to explain about KRR in detail due to the culture tabu. Finally any age seek the information they need through media such as the internet. The higher the age then the more able to analyze the information they get because usually the increasing age of teenagers increasing their formal education from junior high to higher levels such as high school or vocational school (Putra, 2017). The information they gain has an impact on their knowledge and behavior. Therefore, in this study found an association between age and behavior KRR. In the multivariate analysis, it was found that the probability of 0,527 times behaved in favor of KRR. In the study of Son (2017) found that age affects the adolescent in sexual behavior. The results of this study contrasted with research Putri (2014) which concluded that age is not related to behavior.

Similarly, gender was found to have a relationship between sex and behavior. Fisher et al. (2012) results show that male-owned sexual cognitions are larger than females so that adolescent boys are more likely to think about sexual things than women. Culture also plays a protective role between adolescent girls and men where our country places women to always behave more cautiously than boys. This happens because of the assumption that women will bear the consequences if they behave so that women are forced to be more cautious (Tukiran, 2010). Young women are always warned by their parents to be able to take care of themselves compared to male teenagers. According Sarwono (2006) norms that apply to men more loose than the women so that men have an opportunity to perform sex behavior than women. In the multivariate analysis it was found that sex had a chance 2,208 times to behave in favor of KRR, where women had a chance 2,208 times to behave in favor of the KRR. The results of the study were in accordance with Mahmudah (2016) in his study of 158 high school students in Padang City who found that sexual behavior was higher risk in male gender $(37.7 \%)$ than female $(10.3 \%)$, to not support free sexual behavior and tend to support KRR 
Tetti Solehati: Relationship between Age, Gender, and Peer Group with Reproductive Healthy

behavior. This is in line with Lisnawati's (2015) research on adolescent SMKN in Cirebon that shows the relationship between sex and teenage sexual behavior. The results contrasted with the Apriluana (2016) in his study concluded that there was no significant relationship between sex and behavior.

The teenagers are more comfortable to discuss with their peers even though it may be equally insufficient knowledge of his KRR. This can be seen from the result that the teenagers support peer group behavior. The results showed that peer group has 0.211 chance to behave in favor of KRR where the stronger the peer group the more supportive KRR According to Albert (2011), During adolescence, teenagers spend a lot of time with their peers. Peer groups for teenagers have an important role to play in the development of their personalities, one of which was to develop their self-identity and develop interpersonal communication skills in association with their peer group (Septiyuni, 2015). They will communicate something in the group. In addition, the language used in peers was more easily understood by them because in this group of peers there was no reluctance, low self-esteem, shame, and so forth (Desmita, 2009).

In further analysis it was found that there was a relationship between peer group and student KRR behavior. Anindani's research (2015) on the 233 students at SMP Negeri 209 Jakarta proves that there is a positive and significant relationship between peer group and adolescent behavior in dating. The influence of peer groups in adolescents looks so strong because in adolescence they are closer to peers than others. Research Budiarti (2016) on 336 high school students in Jakarta concluded that peers through their interactions have a strong influence in supporting behavior. Research Grace (2013) to junior high school students in Makassar and Pramono (2011) research on high school students in Samarinda showed that peers influence the behavior of adolescents. In Nurhidayah et al. (2012) study on 184 adolescents in Bekasi City concluded that peer group positively affect the behavior teen sex. In multivariate analysis it was found that peer group had 0.211 chance to behave in favor of KRR.
Based on the research result, where age, gender, and peer group can influence adolescent behavior, it was necessary to develop educational methods to change behavior through peer group approach by taking into account the characteristics of age, sex, and peer group. Thus, UKS and PIK-R that have not been running can be reinvigorated by engaging BKS Teacher or Guru UKS. Teenagers can be empowered through health cadres to revive KRR through a peer group approach that is scheduled to continue. So this KRR program comes from them and for them, once they get adequate information from their health teams and teachers. The learning model of KRR through peer group systematically arranged by taking into account the potential awareness of the potential of teenagers in improving their reproductive health status (Azza, 2016).

\section{Conclusion}

Based on the research results can be concluded that there is a relationship between age, sex, and peer group with KRR behavior. To improve the behavior of adolescents, it is suggested that each educational use using methods involving peer group with attention to the characteristics of age and gender eg with peer group teaching, learning method with zigshaw technique, or role play.

\section{References}

Anesia, F., \& Notobroto, H.B. (2013). Faktor yang memengaruhi perilaku seksual pranikah remaja yang bertunangan. Jurnal Biometrika dan Kependudukan, 2(2), 140-147.

Anindani, D.G., Hasanah, U., \& Cholilawati. (2015). Hubungan konformitas peer group dengan perilaku berpacaran pada remaja. Jurnal Kesejahteraan Keluarga dan Pendidikan, 4(1), 51-58.

Albert, D., Chein, J., \& Steinberg, L. (2013). Peer influences on adolescent decision making. Curr Dir Psychol Sci, 22(2), 114-120.

Albert, D., \& Steinberg, L. (2011). Peer influences on adolescent risk 
Tetti Solehati: Relationship between Age, Gender, and Peer Group with Reproductive Healthy

behavior. Inhibitory Control and Drug Abuse Prevention, 211-226.

Apriluana, G., Khairiyati, L., \& Setyaningrum, R. (2016). Hubungan antara usia, jenis kelamin, lama kerja, pengetahuan, sikap dan ketersediaan alat pelindung diri (APD) dengan perilaku penggunaan apd pada tenaga kesehatan. Jurnal Publikasi Kesehatan Masyarakat Indonesia, 3(3), 82-87.

Azza, A., \& Susilo, C. (2016). Peer group as a model for the development learning reproductive health in the Traditional Boarding School.Jurnal Ners, 11(1), 142-146.

BKKBN. (2006). Panduan pengelolaan pusat informasidan konseling kesehatan reproduksi remaja. Jakarta: Direktorat Remaja dan PerlindunganHak-HakReproduksi-BKKBN.

BKKBN. (2012). Pedoman pengelolaan pusat informasi dan konseling remaja dan mahasiswa. Jakarta: Direktorat Bina Ketahanan Remaja.

Budiarti,A.I.(2016).Pengaruhinteraksi dalam peer group terhadap perilaku cyberbullying siswa.Jurnal Pemikiran Sosiologi., 3(1), 1-15.

Crosnoe, R., \& McNeely, C. (2008). Peer relations, adolescent behavior, and public health research and practice. Fam Community Health Supplement 1, 31(1S), S71-S80.

Dariyo, A. (2004). Psikologi perkembangan remaja. Bogor: Ghalia Indonesia.

Delisle, V.D., Gumuchian, S.T., Kloda, L.A., Boruff, J., Baalbaki, G.E., Körner, A., Malcarne, V.L. \& Thombs, B. D. (2016). Effect of support group peer facilitator training programmes on peer facilitator and support group member outcomes: Asystematic review. British Medical Journal Open, 6(11), 1-7.

Desmita, (2009). Model teman sebaya sebagai media pembelajaran. Jakarta: Rineka Cipta.

Fisher, T.D., Moore, Z.T. \& Pittenger, M.J. (2012). Sex on the brain?: An examination of frequency of sexual cognitions as a function of gender, ero $\neg$ tophilia, and social desirability.
The Journal of Sex Research, 49(1), 69-77.

Ford, N., Siregar, K., Ngatimin, R., \& Maidin. (1997). A. the hidden dimension: Sexuality and responding to the threat of HIV/AIDS in South Sulawesi, Indonesia. Health And Place, 3(249-358).

Green, W.L., \& Kreuter, M. (2005). Health program planning an educational and ecological approach (4th Ed.). New York: Mc Graw-Hill Companies.

Hatmadji, S.H., \& Rochani, S. (1993). Adolescent reproductive health in Indonesia. Research Report of Joint Cooperation. Jakarta: Demographic Institute Faculty of Economic University of Indonesia, The Ford Foundation, RAND Corporation, The World Health Organization:Yayasan Kusuma Buana.

Lestari, H., \& Sugiharti. (2011). Perilaku beresiko remaja di Indonesia menurut Survey Kesehatan Reproduksi Remaja Indonesia (SKRRI) Tahun 2007. Jurnal Kesehatan Reproduksi, 1(3), 136-144.

Lisnawati,\&Lestari,N.S.(2015).Faktor-faktor yang berhubungan dengan perilaku seksual remaja di Cirebon. Jurnal CARE, 3(1), 1-8.

Mahmudah, Y.Y., \& Lestari, Y. (2016). Faktor-faktor yang berhubungan dengan perilaku seksual remaja di Kota Padang. Jurnal Kesehatan Andalas, 5(2), 448-455.

Mead, S., \& MacNeil, C. (2005). Peer support: A systemic approach.

Mesra, E., \& Fauziah. (2015). Peran orang tua merupakan faktor dominan terhadap perilaku seksual remaja. Jurnal Ilmu dan Teknologi Kesehatan, 2(2), 35 - 40.

Nurhidayah, S., Prestiana, N.D.I, \& Bayani, I. (2012). Pengasuhan, peer group, self efficacy dan perilaku seks pada remaja di Kota Bekasi. Jurnal Soul., 5(2), 68-79.

Pemerintah Kabupaten Bandung (2011). Narkoba sulit diberantas. http://www. bandungkab.go.id/arsip/1802/narkoba-sulitdiberantas. Diakses tanggal 6 Januari 2016. 
Tetti Solehati: Relationship between Age, Gender, and Peer Group with Reproductive Healthy

Pemerintah Kabupaten Bandung (2014). Pemkab Bandung dan KPA Sabilulungan perangi AIDS. http://www. bandungkab.go.id/arsip/3566/pemkabbandung-dan-kpa-sabilulungan-perangiaids. Diakses tanggal 6 Januari 2016.

Pemerintah Kabupaten Bandung (2010). Korban narkoba, 90 persen anak muda. http://www.bandungkab.go.id/arsip/469/ korban-narkoba, $-90-$ persen-anakmuda. Diakses tanggal 6 Januari 2016.

Pemerintah Kabupaten Bandung. (2013). Kabupaten Bandung "dicintai" para tenaga kerja. humas Setda Kabupaten Bandung. http://www.bandungkab.go.id/ arsip. Di akses tanggal 9 Januari 2017.

Potter \& Perry. (2005). Buku ajar fundamental keperawatan: konsep, proses, dan praktik (Ed. 4, Vol 1-2). Jakarta: EGC.

Pramono, J.S., Deei, A., \& Auliatunida, Z. (2011). Pengaruh teman sebaya terhadap perilaku seksual pada remaja di SMA Negeri 8 Samarinda Tahun 2010. Jurnal Husada Mahakam, 3(2), 45-94.

Putra, I.G.N.E., Pradnyani, P.E., Artini, N.N.A., \& Astiti, N.L.E.P. (2017). Jurnal Kesehatan Masyarakat Andalas, 11(2), 75-83.

Putri, B.D. (2014). Peran faktor keluarga dan karakteristik remaja terhadap perilaku seksual pranikah. Jurnal Biometrika dan Kependudukan, 3(1), 8-19.

Sarwono, S.W. (2006). Psikologi remaja. Jakarta: PT Raja Grafindo Persada.

Septiyuni, D.A., Budimansyah, D., \& Wilodati. (2015). Pengaruh kelompok teman sebaya(peer group) terhadap perilakubullying siswa di sekolah. Jurnal Sosietas, 5(1).

SKRRI. (2007). Pendewasaan usia perkawinan dan hak-hak reproduksi bagi remaja Indonesia. Diakses dari http://ceria. bkkbn.go.id/referensi/substansi/detail/384.

Solehati, T., Ermiati, Trisyani, M., \&
Hermayanti, Y. (2017). Hubungan sumber informasi dan usia remaja puteri dengan perilaku perawatan diri saat menstruasi.Jurnal Keperawatan Padjajaran, 5(2), 145-154.

Solomon, P. (2004). Peer support/peer provided services underlying processes, benefits, and critical ingredients. Psychiatric Rehabilitation Journal, 392-401.

Suryoputro, A., Ford, N.J., \& Shaluhiyah, Z. (2006). Faktor-faktor yang mempengaruhi perilaku seksual remaja di jawa tengah: Implikasinya terhadap kebijakan dan layanan kesehatan seksual dan reproduksi. Makara Kesehatan, 10(1), 29-40.

Tomé, G., Matos, M.G., Simões, C., Camacho, I. \& Diniz, J.A. (2012). How can peer group influence the behavior of adolescents: Explanatory model. Global Journal of Health Science, 4(2), 26 - 35.

Tomé, G., Matos, M.G., Simões, C., Camacho,I. Simões, C., \& Diniz, J.A. (2012). Portuguese adolescents: The importance of parents and peer groups in positive health. Span J Psychol, 15(3), 1315-1324.

Tukiran, dkk. (2010). Keluarga berencana dan kesehatan reproduksi. Yogyakarta: Pusat Studi Kependudukan dan Kebijakan Universitas Gadjah Mada.

Wills, T.A., \& Cleary, S.D. (1999). Peer and adolescent substance use among 6th9th graders: Latent growth analyses of influence versus selection mechanisms. Health Psychol. Sep, 18(5), 453-63.

Wong, D.L., Hockenberry, M., Wilson, D., Winkelstein, M.L., \& Schwartz, P. (2009). Buku ajar keperawatan pediatrik (Ed. 6, Vol. 2). Jakarta: EGC.

You, S. (2011). Peer influence and adolescents' school engagement. ProcediaSocial and Behavioral Sciences, 29, 829-835.

Zahroh, E.S. (2015). Effect of peer support group decrease in dealing with stress on national exam. The Sun, 2(2), 8-13. 